\title{
Implementasi Kansei Engineering pada Aplikasi E-learning Untuk Sekolah Menengah Kejuruan
}

\author{
Yoga Megasyah* \\ Teknik Informatika, Fakultas Ilmu Komputer, Universitas Nasional Pasim \\ Naskah Diterima : 16 Juli 2019; Diterima Publikasi : 24 Oktober 2019 \\ DOI : 10.21456/vol9iss2pp165-176
}

\begin{abstract}
E-learning is the basis and logical consequence of the development of information and communication technology. With Elearning, teaching and learning methods in schools that use technology through electronic media such as computers, laptops, netbooks, or smartphones with internet networks or others. This study uses Kansei Word to detect the feelings of users of Elearning applications. The Kansei Word list is used as many 15 words related to the appearance of the E-learning application. E-learning application specimens used 8 specimens. This study involved 80 participants consisting of 40 students from SMK PGRI 3 Cimahi, 40 students from SMK 4 Padalarang. The questionnaire results from participants were then processed using multivariate statistical analysis, namely Cronbach's Alpha, Coefficient Correlation Analysis (CCA), Principal Component Analysis (PCA), Factor Analysis (FA) and Partial Least Square (PLS) analysis. This study produced 3 recommendations for the design of E-learning application. This recommendation is the result of the Kansei Engineering process which comes from 3 groups of participant data, namely groups of data of all participants, participants of SMK PGRI 3 Cimahi students and participants of SMK 4 Padalarang students.
\end{abstract}

Keywords : Design; Application; E-learning; Kansei Engineering; Kansei Word

\begin{abstract}
Abstrak
E-learning merupakan dasar dan konsekuensi logis dari perkembangan teknologi informasi dan komunikasi. Dengan $E$ learning, metode pengajaran dan pembelajaran di sekolah yang memanfaatkan teknologi melalui media elektronik seperti komputer, laptop, netbook, atau smartphone dengan jaringan internet atau lainnya. Penelitian ini menggunakan Kansei Word untuk mendeteksi perasaan pengguna aplikasi E-learning. Daftar Kansei Word yang digunakan sebanyak 15 kata yang berhubungan dengan tampilan aplikasi E-learning. Spesimen aplikasi E-learning yang digunakan sebanyak 8 spesimen. Penelitian ini melibatkan 80 partisipan yang terdiri dari 40 orang siswa-siswi SMK PGRI 3 Cimahi, 40 orang siswa-siswi SMK Negeri 4 Padalarang. Hasil kuesioner dari partisipan kemudian diolah dengan menggunakan analisis statistik multivariat yakni Cronbach's Alpha, Coefficient Correlation Analysis (CCA), Principal Component Analysis (PCA), Factor Analysis (FA) dan analisis Partial Least Square (PLS). Penelitian ini menghasilkan 3 rekomendasi desain tampilan aplikasi E-learning. Rekomendasi ini merupakan hasil dari proses Kansei Engineering yang bersumber dari 3 kelompok data partisipan, yaitu kelompok data seluruh partisipan, partisipan siswa SMK PGRI 3 Cimahi dan partisipan siswa SMK Negeri 4 Padalarang.
\end{abstract}

Keywords : Desain; Aplikasi; E-learning; Kansei Engineering; Kansei Word

\section{Pendahuluan}

Memasuki era teknologi, siapa pun harus bisa mengerti, menguasai, atau minimal mengenal teknologi jika tidak ingin tertinggal, karena saat ini semua kegiatan manusia berkaitan dengan teknologi. Dunia pendidikan juga sedang menggeliat dengan menerapkan metode E-learning pada sistem pengajarannya. Sistem pembelajaran Electronic learning disingkat E-learning adalah cara baru dalam proses belajar mengajar. E-learning tidak hanya berlaku untuk metode pembelajaran secara online saja, tetapi penerapannya bisa secara offline juga, seperti pembelajaran di kelas dengan menggunakan proyektor atau menonton film dvd guna mempelajari sesuatu mengenai beberapa kejadian aktual seperti kejadian bencana gempa, tsunami, dan sebagainya.

Beberapa masalah ini adalah bagaimana Bagaimana menganalisis faktor-faktor yang diperlukan dalam merancang desain tampilan aplikasi E-learning dengan Kansei Engineering, menganalisis elemen-elemen desain untuk tampilan aplikasi $E$ learning, menerapkan Kansei Engineering dalam menyusun rekomendasi desain tampilan aplikasi $E$ learning. 
Adapun tujuan yang diharapkan dari penelitian ini adalah menganalisis faktor-faktor yang diperlukan dalam merancang desain tampilan aplikasi $E$ learning dengan pendekatan Kansei Engineering, menganalisis elemen-elemen desain untuk tampilan aplikasi E-learning, memberikan rekomendasi penggunaan elemen desain tampilan aplikasi $E$ learning yang dihasilkan melalui pendekatan Kansei Engineering yang sesuai dengan keinginan siswa.

Batasan untuk penelitian ini adalah dilakukan untuk mengembangkan aplikasi E-learning dengan studi kasus di SMK PGRI 3 Cimahi dan SMK Negeri 4 Padalarang, dalam proses analisis Kansei Engineering menggunakan Kansei Engineering Type I atau Kansei Engineering Category Classification, menggunakan Kansei Word untuk mengidentifikasi aspek emosional responden, sumber responden penelitian Kansei Word adalah siswa-siswi SMK PGRI 3 Cimahi dan SMK Negeri 4 Padalarang.

Manfaat dari penelitian yang dilakukan ini diharapkan dapat menjadi alat menerjemahkan kesan siswa dalam bentuk kata atau kalimat ke dalam sebuah bentuk desain dan membuat rancangan tampilan E-learning yang sesuai dengan keinginan dari siswa yang selama ini diaanggap bersifat abstrak.

\section{Kerangka Teori}

\subsection{Pengertian E-learning}

E-learning merupakan suatu jenis belajar mengajar yang memungkinkan tersampaikannya bahan ajar ke siswa dengan menggunakan media internet, intranet, atau media jaringan komputer lain (Hartley, 2001). E-learning adalah sistem pendidikan yang menggunakan aplikasi elektronik untuk mendukung belajar mengajar dengan media internet, jaringan komputer, maupun computer standalone (Yaniawati, 2010).

\subsection{Model pembelajaran E-learning}

Dalam implementasi pembelajaran, terdapat model penerapan E-learning yang bisa digunakan, yaitu (Rusmana, 2011):

1. Selective Model, digunakan jika jumlah komputer di sekolah sangat terbatas (misalkan hanya ada satu unit komputer)

2. Sequential Model, jika komputer di sekolah terbatas dan penggunaan komputer tersebut dilakukan dengan cara bergiliran antar kelompok siswa.

3. Static Station Model, sama halnya seperti sequential model, yang mana guru telah memiliki sumber belajar yang telah disimpan di aplikasi lalu siswa secara berkelompok mengakses sumber belajar tersebut.

4. Laboratory Model, adanya laboratorium komputer yang telah terhubung ke internet, dimana siswa dapat menggunakan komputer dengan lebih leluasa.

\subsection{Human Computer Interaction (HCI)}

Suatu disiplin ilmu yang berkaitan dengan desain, evaluasi, dan implementasi komputasi interaktif (Kurosau, 2016). Serangkaian proses, dialog dan tindakan yang dilakukan antara manusia dan computer (Wiley, 2015). Dengan demikian terlihat jelas bahwa fokus HCI tidak hanya pada keindahan tampilannya saja, tetapi juga memperhatikan aspekaspek pemakai, implementasi sistem rancangannya dan fenomena lingkungannya.

\subsection{Kansei Engineering}

Kansei Engineering adalah teknologi yang menyatukan kansei dalam bidang rekayasa. Bidang dimana pengembangan produk yang menyenangkan dan memuaskan manusia yang dilakukan teknologi. Hal ini dilakukan dengan menganalisis kansei manusia dan menggabungkan mereka ke dalam desain produk (Lokman, 2009a). Kansei Engineering merupakan sebuah teknologi yang menggabungkan Kansei ke dalam dunia rekayasa dalam mewujudkan produk yang sesuai dengan kebutuhan dan keinginan konsumen. Dengan kata lain Kansei Engineering adalah teknologi dalam bidang ergonomi yang berorientasi pada pelanggan untuk pengembangan produk termasuk di dalam produk software.

Proses dari Kansei Engineering dimulai dari kansei investigation, dilanjutkan ke tahapan kansei analysis dan berakhir pada proses product design. Seperti yang digambarkan pada Gambar 1.

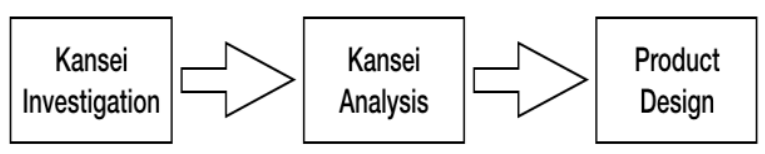

Gambar 1. Diagram metode Kansei Engineering (Nagamachi, 2011)

Dalam tahapan awal Kansei Engineering, dilakukannya investigasi terhadap user menggunakan metode psiko-fisiologis. Hasil dari investigasi merupakan sebuah data yang selanjutnya dilakukan analisis menggunakan psychological equipment. Data yang telah dianalisis maka akan diinterpretasikan ke dalam desain produk melalui teknik Kansei Engineering.

Kansei Engineering yang sering digunakan terdapat enam kategori (Lokman, 2013):

1. KE Type I: Category Classification

Penurunan teknik dari konsep target sebuah produk baru yang terkait dalam subjektif Kansei dengan objektif dari parameter desain. Contoh dari penerapan $\mathrm{KE}$ tipe 1 ini adalah dalam pengembangan sport car tersuskses dalam sejarah Mazda yang bernama Miata.

2. KE Type II: KE System (KES) 
Terdiri dari database dan mesin inferensi untuk mendukung sistem komputerisasi yang menangani proses menafsirkan perasaan konsumen dan emosi untuk elemen desain persepsi. Proses KES berdasar pada aturan "if - then" dimana Kansei diinput ke dalam sistem, mengacu pada database Kansei dan mengeksekusi perangkat inferensi.

\section{KE Type III: KE Modeling}

$\mathrm{KE}$ tipe ini memanfaatkan pemodelan matematika Sebagai pelogikaan dalam sistem komputerisasi. Hal ini terutama digunakan untuk menangani logika fuzzy untuk membentuk kecerdasan mesin. Sistem diagnosa suara kata adalah sebuah contoh implementasi dari KE tipe ini.

\section{KE Type IV: Hybrid KE}

Sebuah sistem KE yang dimulai dengan evaluasi Kansei dan analisis data kemudian diterjemahkan ke dalam elemen desain dinamakan Forward KE. Dalam Hybrid KE memungkinan melakukan Backward KE yang merupakan alur mundur dari Forward KE. Setelah desainer mensketsa prototype yang direkomendasi melalui forward $\mathrm{KE}$, protype tersebut dievaluasi melalui Backward KE.

\section{KE Type V: Virtual KE}

Merupakan gabungan Kansei Engineering dengan simulasi virtual, mengadopsi dari Virtual Reality System yang dikembangkan oleh NASA untuk membuat simulasi ruang angkasa sehingga menjadi nampak nyata.

6. KE Type VI: Collaborative KE

Dalam jenis Kansei Engineering, desainer dan atau konsumen di tempat yang berbeda menggunakan database mutual Kansei dan berkolaborasi melalui jaringan untuk mengembangkan desain produk baru.

\subsection{Kansei Engineering Type I}

Kansei Enginering Type I merupakan metodologi Kansei yang paling popular dan digunakan dalam penelitian ini, tipe ini dinamakan dengan KEPack (Lokman, 2010). Tahapan KEPack terdiri dari 10 alur seperti ditunjukan pada Gambar 2.

1. Menentukan Strategi

Merupakan tahapan awal dalam KEPack, penguasaan teoritis dan konsep Kansei Engingeering dilakukan pada tahapan ini. "Menentukan Strategi" juga berarti menentukan berapa jumlah Kansei Word (KW) maupun spesimen yang dibutuhkan, berapa jumlah partisipan yang dilibatkan dan metode Kansei yang dilakukan.

\section{Menentukan Kansei Word}

Kansei Word yang berupa kata kunci berhubungan dengan emosional atau afektif manusia. Menentukan Kansei Word sangat mempengaruhi kesuksesan dari penelitian Kansei. Akan ada perbedaan lingkup Kansei Word, misalnya dalam meneliti produk olahan makanan akan berbeda dengan melakukan penelitian terhadap bahan pakaian. Salah satu langkah yang digunakan dalam menentukan Kansei Word dapat kita temukan misalnya, di majalah atau buku yang berhubungan dengan produk yang diteliti seperti majalah fashion digunakan dalam mencari Kansei Word produk bahan pakaian, ataupun dengan mendengar percakapan penjualan antara pembeli dan penjual. Kita pun dapat mengkompilasikan Kansei Word berdasar pendapat ahli maupun studi teoritis.

3. Menyusun Struktur Skala Semantic Differential (SD) untuk Kanse Word

Setelah dilakukan investigasi Kansei melalui pemilihan Kansei Word yang berkaitan dengan penelitian yang diteliti, langkah berikutnya yakni menyusun Kansei Word tersebut menjadi struktur skala Semantic Differential (SD). Skala SD digunakan untuk mempermudah partisipan dalam pengisian kuisioner.

4. Mengumpulkan sampel produk

Mengumpulkan sampel produk/spesimen atau yang selanjutnya disebut dengan Preparation of Specimen. Ada 4 tahapan dalam Preparation of Specimen (Lokman, 2009b), yaitu:

a. Identifikasi Spesimen Awal

b. Investigasi Elemen Desain

c. Klasifikasi Elemen Desain (dilakukan pada tahapan kelima)

d. Finalisasi Spesimen valid (dilakukan pada tahapan kelima)

5. Mengklasifikasikan Item atau Kategori

Dua langkah dilakukan dalam tahapan ini, mengacu pada Preparation of Specimen, yakni klasifikasi elemen desain dan finalisasi spesimen valid.

6. Evaluasi Penelitian

Langkah berikutnya yakni evaluasi penelitian, pada tahapan ini partisipan terlibat mengisi Skala SD dengan Kansei Word yang sudah disusun sebelumnya.

7. Analisis Menggunakan Metode Statistik Multivariat

Analisis dalam Kansei Engineering, dilakukan dengan statistik multivariat, dimana dapat mempertimbangkan sekian banyak faktor untuk menjelaskan hubungan yang terjadi dalam sebuah fenomena yang kompleks.

8. Interpretasi Analisis Data

Dalam menganalisis persyaratan desain, Partial Least Square (PLS) dilakukan untuk mengidentifikasi hubungan dari emosi dan elemen desain.

9. Interpretasi Data pada Desainer

Langkah berikutnya adalah menerjemahkan data tersebut ke dalam matriks yang mudah dipahami oleh desainer web.

10. Menggabungkan Sketsa Desainer dengan Proposan Kansei Engineering

Tahapan ini merupakan tahap implementasi dari penelitian Kansei Engineering, namun dalam penelitian ini hanya dilakukan sampai pada tahap 9. 
Dalam tahapan ini sejumlah ahli dan web desainer dilibatkan, ide dalam penelitian Kansei Engineering dituangkan ke dalam perancangan web dan menghasilkan desain final yang dinamakan "Super Design” (Lokman, 2010).

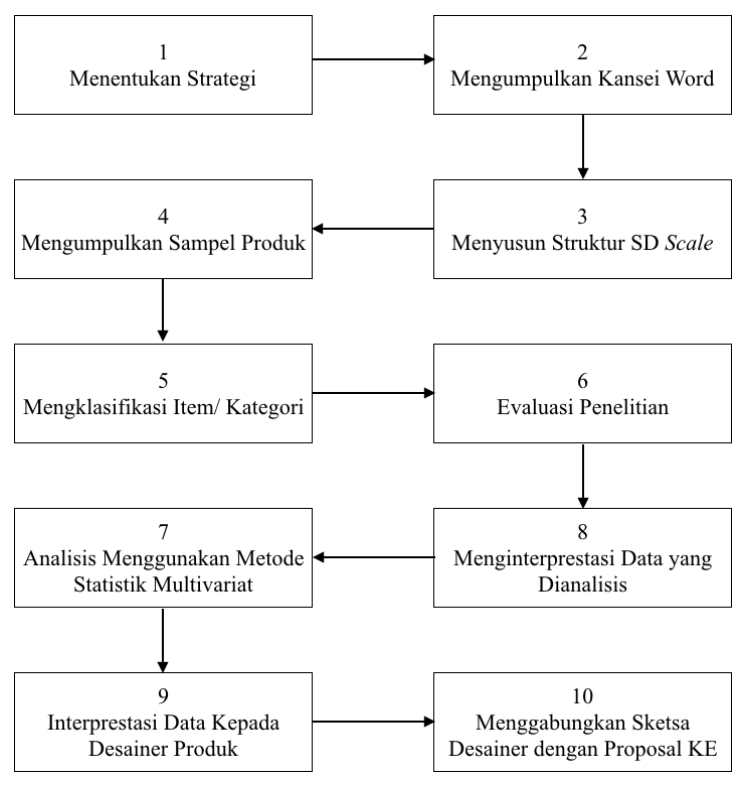

Gambar 2. Tahapan Kansei Engineering Type I (Lokman, 2010)

\subsection{Analisis Statistik Multivariat}

Analisis statistik multivariat digunakan untuk beberapa variabel yang memiliki hubungan antar variabel saling berkorelasi. Terdapat empat analisis statistik yang digunakan dalam analisis ini yaitu (Lokman, 2009c):

1. Cronbach's Alpha

Cronbach's Alpha adalah metode untuk mengukur reliabilitas data. Koifisien reliabilitas berkisar antara 0-1. Semakin mendekati angka 1 semakin besar tingkat reliabilitasnya. Patokan nilai yang umumnya digunakan adalah 0,7. Apabila nilai hasil dari uji reliabilitas di atas 0,7 maka data dianggap reliable.

\section{Coefficient Correlation Analysis}

Coefficient Correlation Analysis atau yang sering disebut dengan analisis korelasi Pearson ditemukan pertama kali oleh Karl Pearson. Korelasi Pearson berguna untuk mengetahui hubungan beberapa variabel.

\section{Principal Component Analysis (PCA)}

PCA secara aljabar merupakan kombinasi linear khusus untuk $\mathrm{p}$ variable random $\mathrm{X} 1, \ldots, \mathrm{Xp}$. Secara geometri, kombinasi linear menyatakan pemilihan sistem koordinat baru yang diperoleh dari merotasi sistem mula-mula $\mathrm{X} 1, \ldots \mathrm{Xp}$ sebagai sumbu-sumbu koordinat. Sumbu koordinat yang baru sangat tergantung dari matriks kovariansi (atau matriks korelasi). Dalam penelitian ini PCA dilakukan untuk mereduksi 20 axis dari emosi ke dalam dua atau tiga axis dengan langkah awal menentukan nilai eigenvalue. PCA membantu untuk memahami struktur emosi (yang diinterpretasikan oleh Kansei Word) secara jelas dan menjelaskan respon partisipan lebih konstruktif.

4. Factor Analysis (FA)

Tujuan dari analisis faktor adalah menggambarkan hubungan-hubungan kovarian antara beberapa variabel yang mendasar tetapi tidak teramati, kualitas random yang disebut faktor.

5. Analisis Partial Least Square (PLS)

PLS merupakan metode analisis yang powerfull karena dapat diterapkan pada semua skala data, tidak membutuhkan banyak asumsi dan ukuran sampel tidak harus besar. PLS selain dapat digunakan sebagai konfirmasi teori juga dapat digunakan untuk membangun hubungan yang belum ada landasan teorinya atau untuk pengujian proposisi. PLS juga dapat digunakan untuk pemodelan struktural dengan indikator bersifat reflektif maupun formatif (Mindrajaya dan Sumertajaya, 2008).

\section{Metode}

\subsection{Metode Penelitian}

Metode Kansei Engineering Type I digunakan pada penelitian ini, dikarenakan metode tersebut sangat cocok diterapkan pada aplikasi E-learning. Adapun tahapan untuk melakukan penelitian ini dapat dilihat pada Gambar 3.

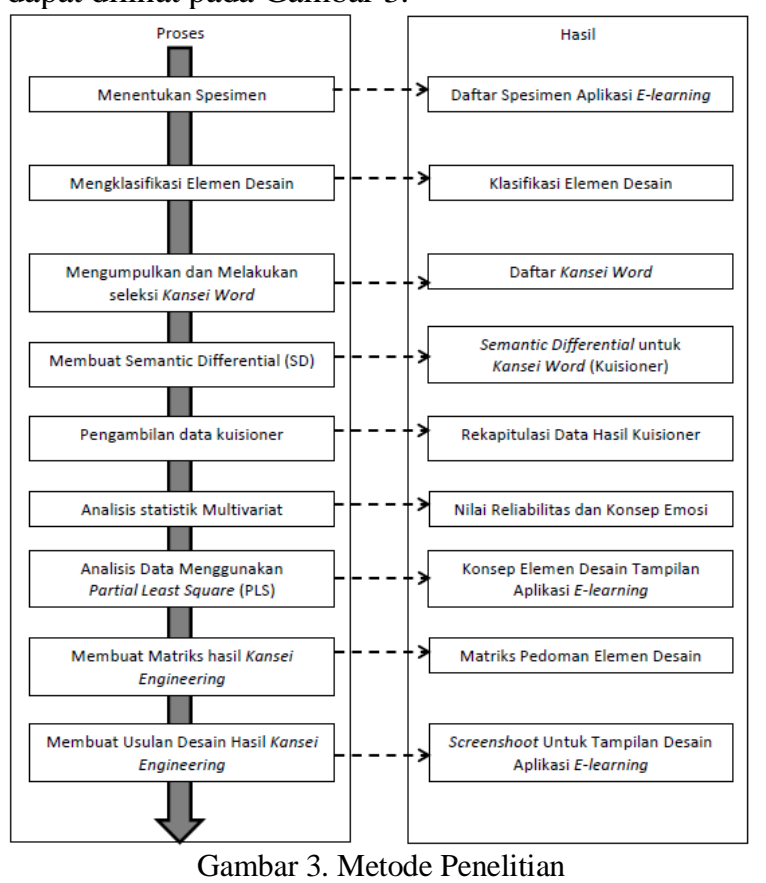

1. Melakukan seleksi Spesimen E-learning

Pada awalnya terdapat 20 kandidat spesimen yang merupakan hasil pencarian menggunakan search engine google dengan kata kunci pencarian "website E-learning". Dari 20 kandidat spesimen, untuk spesimen tampilan dipilih perbedaan tampilan yang 
mencolok dan dapat dibuka menggunakan desktop browser.

2. Mengklasifikasikan Elemen Desain

Sebagai bahan pembanding berdasarkan aturan, spesimen yang valid untuk pengukuran kansei dapat melalui proses sintesis dari semua spesimen awal. Sesuai dengan literatur sebelumnya yang telah mengklasifikasikan context desain aplikasi menjadi konten, tata letak dan teknologi. Elemen desain dalam penelitian ini meliputi context isi dan tata letak, yang mencakup elemen desain seperti penempatan logo, tab, gambar serta desain visual seperti background, warna dan juga tipografi. Proses identifikasi spesimen dimulai dengan pemilihan desain antarmuka beberapa aplikasi E-learning. Sejumlah aplikasi E-learning dipilih sebagai spesimen awal berdasarkan perbedaan desain, baik dalam content dan context, yaitu warna, tipografi, tata letak dan elemen pembentuk lainnya.

3. Mengumpulkan dan Menentukan Kansei Word

Kansei Word yang selanjutnya digunakan untuk kuisioner bagi partisipan berupa kata sifat (adjective) atau kata benda (noun). Penentuan Kansei Word menjadi dasar bagi tahapan berikutnya. Dalam penelitian ini Kansei Word didapatkan dari literatur yang berkaitan dengan E-learning dan pemikiran subjektif.

4. Menyusun Semantic Differential (SD)

Dalam menyusun skala Semantic Differential (SD) akan menggunakan dua kata sebagai Kansei Word dengan menggunakan skala 5 poin.

5. Proses Pengambilan Data Kuisioner dan Partisipan

Sebanyak 20 - 30 orang cukup untuk dijadikan subyek dalam penelitian Kansei (Lokman, 2010) sehingga penelitian ini melibatkan 80 orang siswa SMK dengan usia rata-rata antara 16-18 tahun. Pengisian data kuisioner dilakukan di ruang kelas dengan menyertakan juga tampilan dari spesimenspesimen e-learning. Delapan spesimen valid berupa tampilan E-learning berbasis web dan diberikan kepada siswa tersebut dengan lembar Kansei Word yang sudah distrukturisasi skala SD untuk menjadi bahan pengisian. Data-data tersebut kemudian direkap dan dirata-ratakan secara manual dengan menggunakan Microsoft Excel.

6. Analisis Statistik Multivariat

Data rata-rata yang sudah dihasilkan pada tahapan sebelumnya, akan diolah dengan metode statistik multivariate (Cronbach's Alpha, CCA, PCA dan FA).

7. Menerjemahkan Data Statistik ke dalam Elemen Desain

Tahap ini masih berkaitan dengan tahapan sebelumnya yaitu melakukan perhitungan analisis statistik PLS digunakan untuk menginterpretasi data statistik ke dalam elemen desain.
8. Membuat Matriks Hasil Analisis Kansei Engineering

Hasil perhitungan analisis multivariat pada tahap sebelumnya telah menghasilkan konsep emosi dan elemen desain. Tahap selanjutnya adalah pembuatan matriks hasil analisis Kansei Engineering. Matriks ini akan menjadi pedoman untuk pembuatan desain tampilan Aplikasi E-learning. Isi dari matriks ini adalah elemen desain yang memenuhi konsep emosi Kansei Engineering. Kriteria elemen desain yang terpilih akan diterjemahkan ke dalam bentuk file CSS pada tahap selanjutnya.

9. Membuat Usulan Desain Hasil Kansei Engineering

Tahap terakhir pada penelitian ini adalah pembuatan usulan desain, hasil analisis Kansei Engineering yang telah dilakukan pada tahap sebelumnya akan dijadikan pedoman untuk membuat prototype desain tampilan aplikasi E-learning.

\section{Hasil dan Pembahasan}

\subsection{Menentukan Spesimen}

Spesimen yang merupakan hasil pencarian menggunakan search engine google dengan kata kunci pencarian "website E-learning", mendapatkan 20 kandidat spesimen yang dapat dilihat pada Tabel 1.

Tabel 1. Perangkat Lunak E-learning

\begin{tabular}{cll}
\hline No & $\begin{array}{l}\text { Perangkat Lunak } E- \\
\text { learning }\end{array}$ & \multicolumn{1}{c}{ Alamat Website } \\
\hline 1 & Moodle & https://moodle.org \\
2 & Edmodo & https://www.edmodo.com \\
3 & ConnectEdu & https://www.connectedu.net \\
4 & Blackboard & http://www.blackboard.com \\
5 & SumTotalSystem & http://www.sumtotalsystems.co \\
& & $\mathrm{m}$ \\
6 & CornerStone & http://www.cornerstoneondeman \\
7 & Schoology & d.com \\
8 & SuccessFactors & https://www.schoology.com \\
& SAP) & http://www.successfactors.com \\
9 & Collaborize & http://www.collaborizeclassroom \\
10 & Classroom & .com \\
11 & ChillSoft & http://www.skillsoft.com \\
12 & ATutor & https://chamilo.org \\
13 & Instructure & http://www.atutor.ca \\
14 & Quipper School & http://www.instructure.com \\
15 & Interactyx & http://www.quipperschool.com \\
16 & DigitalChalk & http://interactyx.com \\
17 & Latitude Learning & http://www.digitalchalk.com \\
18 & eFront & http://www.latitudelearning.com \\
19 & Opigno & http://www.efrontlearning.net \\
20 & Meridian & https://www.opigno.org \\
& & http://www.meridianks.com \\
\hline
\end{tabular}

Dari 20 kandidat spesimen, satu spesimen yang digunakan dalam pembelajaran di sekolah berdasarkan kurikulum yang telah ditentukan oleh Kementrian Pendidikan dan Kebudayaan yaitu Edmodo, namun untuk spesimen tampilan dipilih berdasarkan elemen desain yang mempunyai perbedaan tampilan yang mencolok dan dapat dibuka menggunakan desktop browser, hanya delapan spesimen yang terpilih sebagaimana tersaji pada Tabel 2. 
Tabel 2. Spesimen E-learning Terpilih

\begin{tabular}{cll}
\hline No & \multicolumn{1}{c}{$\begin{array}{c}\text { Perangkat } \\
\text { Lunak } E- \\
\text { learning }\end{array}$} & \multicolumn{1}{c}{ Alamat Website } \\
\hline 1 & Edmodo & https://www.edmodo.com \\
2 & Schoology & https://www.schoology.com \\
3 & QuipperSchool & https://www.quipperschool.com \\
4 & Succes Factors & http://www.successfactors.com \\
5 & Chamilo & https://chamilo.org \\
6 & Corner Stone & http://www.cornerstoneondemand.com \\
7 & on Demond & \\
8 & ATutor & http://www.atutor.ca \\
\hline
\end{tabular}

Secara visualisasi screenshot dari 8 (delapan) spesimen dapat dilihat pada Tabel 3, aspek desain interface menjadi fokus penelitian yang diuraikan ke dalam komponen layout posisi header, right menu, left menu, footer, top menu dan Body.

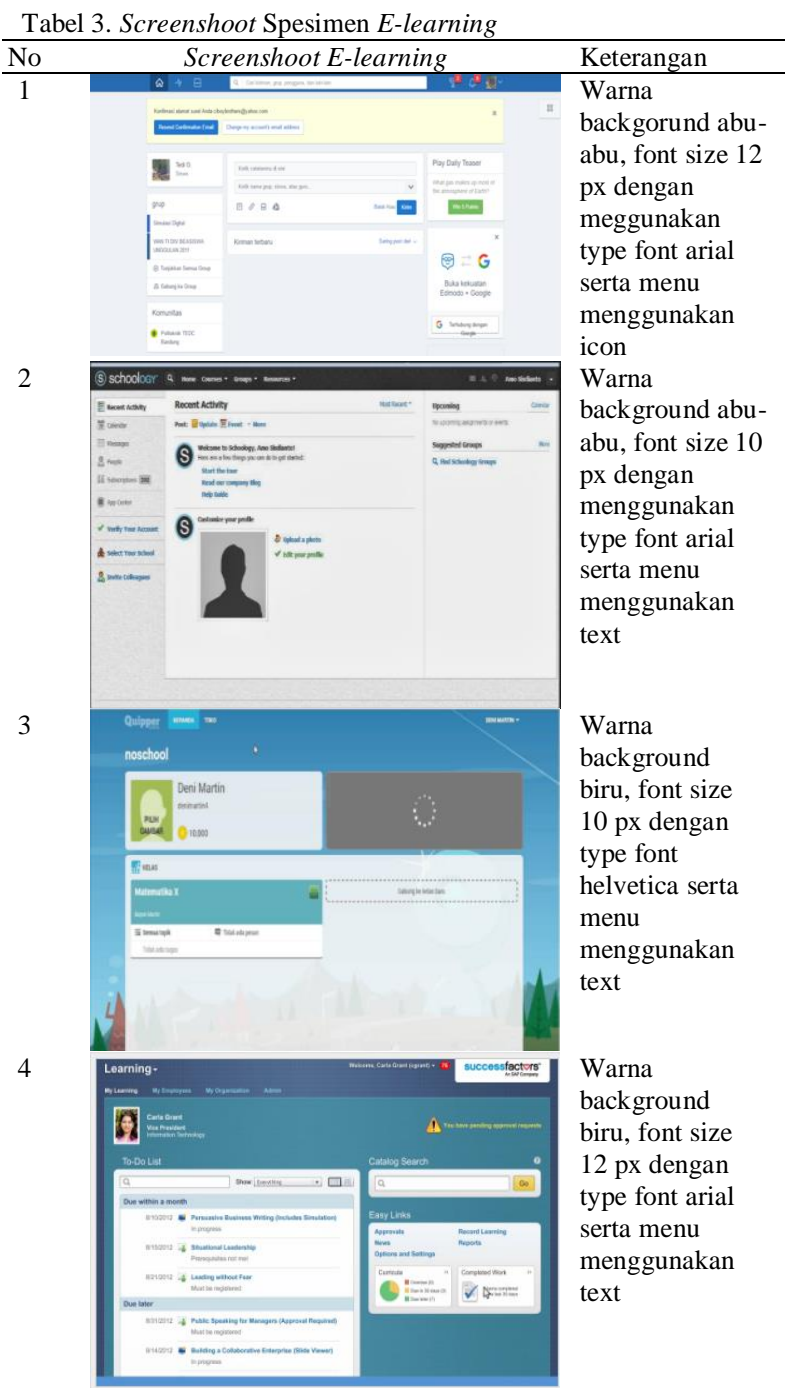

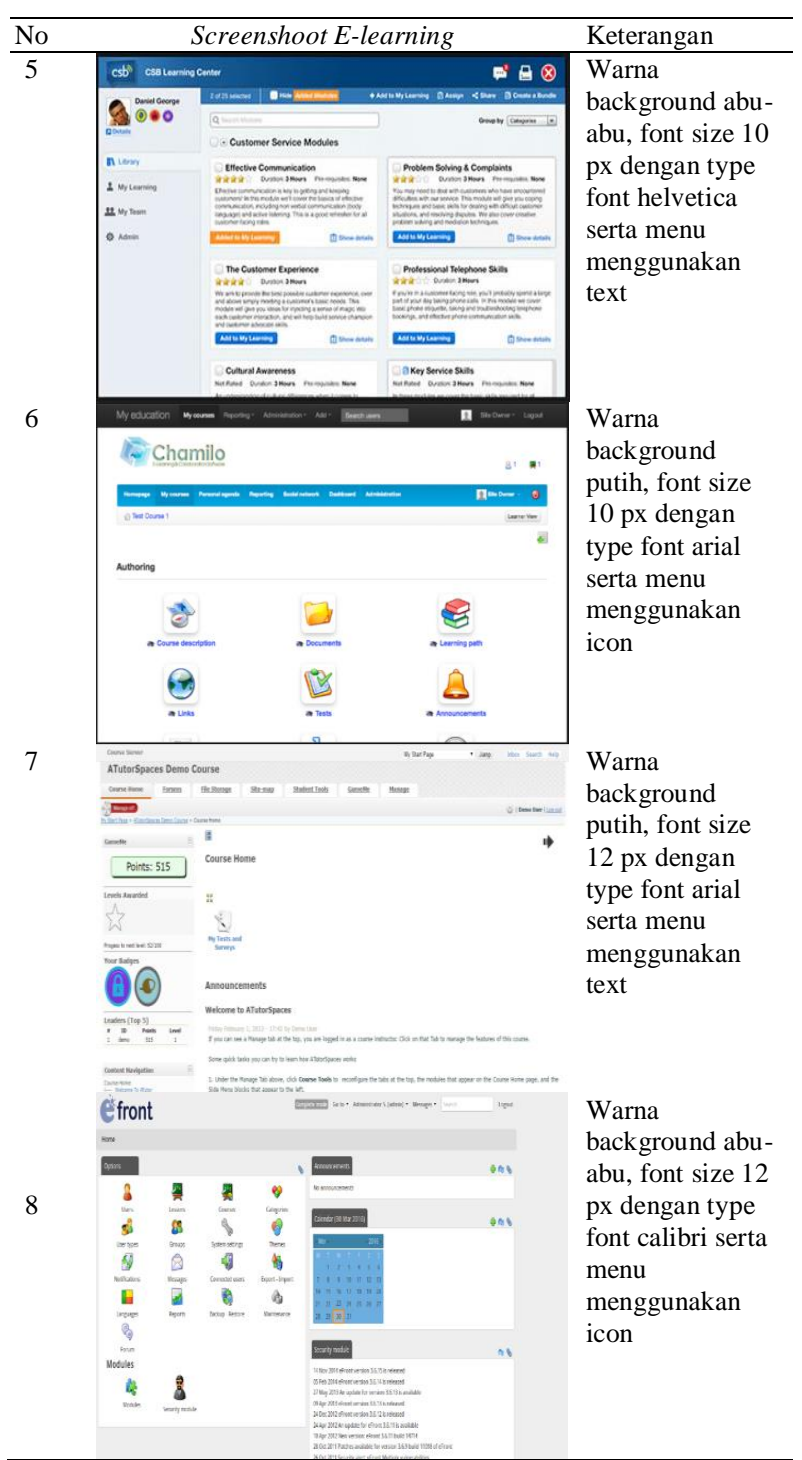

4.2. Klassifikasi Elemen Desain

Untuk mempermudah langkah berikutnya, delapan spesimen tersebut dikategorikan berdasarkan elemen desain, seperti pada Tabel 4. Delapan kategori utama elemen desain meliputi : Background, Body, Top Menu, Main Menu, Right Menu, Left Menu, Footer, Search Bar. Tiga puluh enam sub elemen desain yang merupakan penjabaran dari 8 kategori utama. 
Tabel 4. Matriks Elemen Desain

\begin{tabular}{|c|c|c|c|c|c|c|c|c|}
\hline \multirow{4}{*}{ E-learning } & \multicolumn{3}{|c|}{ Background } & \multicolumn{5}{|c|}{ Body } \\
\hline & \multicolumn{3}{|c|}{ Color } & \multicolumn{2}{|c|}{ Font Size } & \multicolumn{3}{|c|}{ Font Type } \\
\hline & White & Gray & Blue & $10 \mathrm{px}$ & $12 \mathrm{px}$ & Arial & Calibri & Helvetica \\
\hline & $\mathrm{BCW}$ & BCG & $\mathrm{BCB}$ & BFS10 & BSF12 & BFTA & BFTC & BFTH \\
\hline Edmodo & 0 & 1 & 0 & 0 & 1 & 1 & 0 & 0 \\
\hline Schoology & 0 & 1 & 0 & 1 & 0 & 1 & 0 & 0 \\
\hline Quipper School & 0 & 0 & 1 & 1 & 0 & 0 & 0 & 1 \\
\hline Succes Factors & 0 & 0 & 1 & 0 & 1 & 1 & 0 & 0 \\
\hline Corner Stone on Demond & 0 & 1 & 0 & 1 & 0 & 0 & 0 & 1 \\
\hline Chamilo & 1 & 0 & 0 & 1 & 0 & 1 & 0 & 0 \\
\hline ATutor & 1 & 0 & 0 & 0 & 1 & 1 & 0 & 0 \\
\hline Efront & 0 & 1 & 0 & 0 & 1 & 0 & 1 & 0 \\
\hline
\end{tabular}

\subsection{Pemilihan Kansei Word}

Daftar Kansei Word yang digunakan pada penelitian ini sebanyak 15 Kansei Word, dapat dilihat pada Tabel 5 .

Tabel 5. Daftar Kansei Word

\begin{tabular}{|c|c|}
\hline Kansei Word & Keterangan \\
\hline Dinamis & Memberikan kesan fleksibel, tidak kaku \\
\hline Modern & Memberikan kesan teknologi canggih \\
\hline Inofatif/ Kreatif & Memberikan kesan penuh daya cipta \\
\hline Sederhana & Menimbulkan kesan apadanya, simple \\
\hline Alami & Memberikan kesan natural / alami \\
\hline Serasi & $\begin{array}{l}\text { Memberikan keselarasan warna, kontras, } \\
\text { matching }\end{array}$ \\
\hline Unik & $\begin{array}{l}\text { Memberikan kesan berbeda, hal yang } \\
\text { tidak biasa }\end{array}$ \\
\hline Colorfull & Memberikan kesan penuh warna \\
\hline Fun & Memberikan kesan menyenangkan \\
\hline Indah & Memberikan kesan enak untuk dilihat \\
\hline Formal & $\begin{array}{l}\text { Memberikan kesan dewasa, sesuai dengan } \\
\text { aturan }\end{array}$ \\
\hline Bersemangat & Menimbulkan kesan semangat \\
\hline Informatif & $\begin{array}{l}\text { Memberikan kesan mudah dilihat dan } \\
\text { sesuai }\end{array}$ \\
\hline Elegan & Memberikan kesan, elok rapi anggun \\
\hline Mudah & $\begin{array}{l}\text { Memberikan kesan mudah dalam } \\
\text { penggunaan }\end{array}$ \\
\hline
\end{tabular}

\subsection{Proses Pengambilan Data}

Kemudian penyebaran kuisioner terhadap 80 orang yang terdiri dari siswa-siswi SMK Negeri 4 Padalarang dan SMK PGRI 3 Cimahi.

Tabel 6. Rata-rata Hasil Rekapitulasi Seluruh Responden

\begin{tabular}{lccc}
\hline \multicolumn{1}{c}{ Kansei Word } & Edmodo & Schoology & $\begin{array}{c}\text { Quipper } \\
\text { School }\end{array}$ \\
\hline Dinamis & 4.025 & 3.675 & 4.5125 \\
Modern & 3.9 & 3.625 & 4.55 \\
Inofatif/ Kreatif & 3.7125 & 3.6 & 4.4875 \\
Sederhana & 4.1375 & 4.1 & 4.075 \\
Alami & 3.7125 & 3.8375 & 4.2125 \\
Serasi & 4.0625 & 3.575 & 4.5 \\
Unik & 3.125 & 3.425 & 4.3625 \\
$\ldots$ & & & \\
\hline
\end{tabular}

\subsection{Hasil Analisis Multivariat}

Untuk mendapatkan Gambaran konsep Kansei Word dari delapan spesimen yang mewakili website E-learning yang dapat diakses melalui browser desktop, karena terdapat beberapa relasi antar variabel maka analisis statistik multivariat yang dilakukan akan menggunakan Coefficient Correlation Analysis (CCA), Principal component Analysis (PCA) serta Factor Analysis (FA). Dari ketiga metode tersebut kemudian menghasilkan data output namun sebelum masuk ke hasil analisis dari tiga metode analisis statistik multivariat sebaiknya harus dilihat dulu nilai realibilitas menggunakan Cronbach's Alpha. Berikut hasil dari perhitungan reabilitis menggunakan Cronbach's Alpha:

\section{Cronbach's Alpha}

Analisis pertama dilakukan adalah Cronbach's Alpha yang berguna untuk mengukur tingkat reliabilitas data dari responden yang terlibat dalam pengisian kuesioner seperti pada Tabel 7.

Tabel 7. Reliabilitas Menggunakan Cronbach's Alpha

\begin{tabular}{lc}
\hline Responden & Cronbach's Alpha \\
\hline Data seluruh responden & 0.956 \\
Data responden SMK PGRI 3 Cimahi & 0.952 \\
Data responden SMK Negeri 4 & 0.957 \\
Padalarang & \\
\hline
\end{tabular}

Dari hasil perhitungan analisis Cronbach's Alpha seluruh kelompok responden memiliki nilai lebih besar dari 0,7. Artinya seluruh data reliable dan dapat digunakan untuk perhitungan analisis multivariat selanjutnya.

2. Coefficient Correlation Analysis (CCA)

Operasi perhitungan statistik menggunakan CCA dengan metode Correlation Pearson sehingga menghasilkan data analisis seperti pada Tabel 8 .

Tabel 8. Hasil CCA Seluruh Responden Menggunakan Correlation Pearson

\begin{tabular}{lcccc}
\hline \multicolumn{1}{c}{ Variabel } & Dinamis & Modern & $\begin{array}{r}\text { inofatif/ } \\
\text { Kreatif }\end{array}$ & $\ldots$ \\
\hline Dinamis & 1 & 0.891 & 0.911 & $\ldots$ \\
Modern & 0.891 & 1 & 0.956 & $\ldots$ \\
inofatif/ Kreatif & 0.911 & 0.956 & 1 & $\ldots$ \\
Sederhana & 0.225 & -0.204 & -0.079 & $\ldots$ \\
Alami & 0.572 & 0.238 & 0.414 & $\ldots$ \\
Serasi & 0.916 & 0.872 & 0.829 & $\ldots$ \\
Unik & 0.786 & 0.829 & 0.938 & $\ldots$ \\
Colorfull & 0.833 & 0.905 & 0.949 & $\ldots$ \\
Fun & 0.952 & 0.916 & 0.961 & $\ldots$ \\
\hline
\end{tabular}




\begin{tabular}{lclll}
\hline \multicolumn{1}{c}{ Variabel } & Dinamis & Modern & $\begin{array}{c}\text { inofatif/ } \\
\text { Kreatif }\end{array}$ & $\ldots$ \\
\hline Indah & 0.922 & 0.915 & 0.923 & $\ldots$ \\
Formal & 0.326 & 0.288 & 0.101 & $\ldots$ \\
Bersemangat & 0.935 & 0.824 & 0.873 & $\ldots$ \\
Informatif & 0.755 & 0.575 & 0.528 & $\ldots$ \\
Elegan & 0.858 & 0.711 & 0.724 & $\ldots$ \\
Mudah & 0.721 & 0.392 & 0.389 & $\ldots$ \\
\hline
\end{tabular}

Dengan mengacu kepada data yang terdapat pada Tabel 8 dapat terlihat adanya korelasi yang tinggi diantara Kansei Words namun disisi lain juga ada korelasi yang rendah diantara Kansei Words untuk CCA seluruh responden.

\subsection{Principal Component Analysis (PCA)}

PCA dilakukan untuk mengetahui hubungan antara spesimen dengan Kansei Words dengan mereduksi faktor Kansei Words yang tidak terlalu signifikan. Analisis PCA menggunakan tools XLStat versi 2017.19.02 dengan melibatkan data rekapitulasi rata-rata partisipan sebagai bahan analisis data. Berdasarkan perhitungan analisis PCA tersebut maka dapat dihasilkan beberapa faktor atau disebut dengan Principal component (PC) seperti pada Tabel 9.

Tabel 9. Nilai Primcipal Component untuk Seluruh Responden

\begin{tabular}{lllllll}
\hline & PC1 & PC2 & PC3 & PC4 & PC5 & PC6 \\
\hline Eigenvalue & 10.2 & 2.58 & 1.09 & 0.50 & 0.31 & 0.15 \\
& 71 & 1 & 5 & 7 & 0 & 6 \\
Variability & 68.4 & 17.2 & 7.29 & 3.37 & 2.06 & 1.04 \\
$(\%)$ & 71 & 04 & 8 & 8 & 9 & 3 \\
Cumulative & 68.4 & 85.6 & 92.9 & 96.3 & 98.4 & 99.4 \\
$(\%)$ & 71 & 76 & 74 & 52 & 21 & 64 \\
\hline
\end{tabular}

Nilai eigenvalue PC1 dan PC2 memiliki sebesar 10.271 dan 2.581 kemudian dengan tingkat variability pada PC1 sebesar $68.471 \%$, PC2 sebesar 17.204. Pada baris cumulative menunjukkan akumulasi hingga PC2 sebesar $85.676 \%$, hal tersebut mengartikan bahwa nilai PC1 dan PC2 sudah mewakili dari analisis data atau pengaruh terhadap emotion. Dikarenakan sudah diwakili oleh nilai PC1 dan PC2 dengan tingkat cumulative di atas 80\% maka didapat dua faktor yaitu PC1 dan PC2, yang selanjutnya disebut F1 dan F2.

Pada tahapan selanjutnya F1 dan F2 akan dikalkulasikan untuk memberikan gambaran hubungan emotion maupun spesimen, yaitu:

1. PC Loading F1 dan F2

PC Loading digunakan untuk menganalisis ruang semantik Kansei Words untuk menunjukkan berapa banyak evaluasi Kansei Words mempengaruhi variabel.

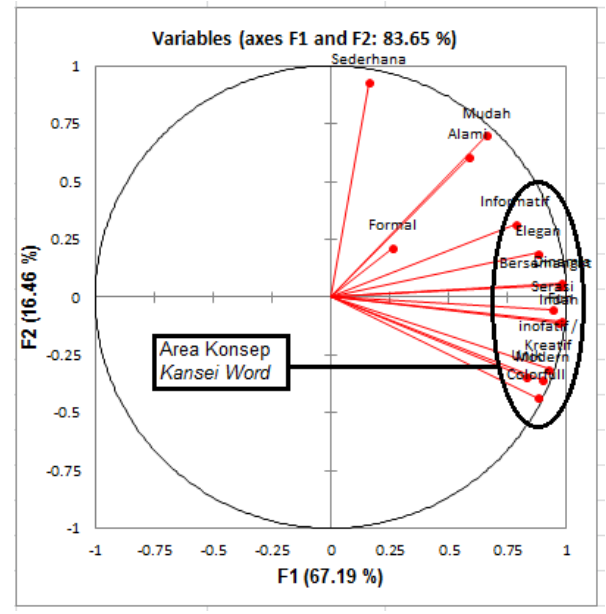

Gambar 4. PC Loading F1 dan F2 untuk Seluruh Responden

Terlihat pada Gambar 4 seluruh Kansei Words berada pada quadran satu dan quadran empat sedangkan Kansei Words "Mudah" berada pada quadran satu sedangkan "Indah" dan "Colorfull" berada dalam wilayah quadran empat. Namun jika dilihat pada posisi axis $\mathrm{x}$ dapat kita lihat pada axis $\mathrm{x}$ positif seluruh Kansei Words berkumpul dalam wilayah axis x positif tersebut. Kansei Words yang mempunyai nilai $\mathrm{x}$ terbesar akan menjadi acuan konsep Kansei Words seperti yang telah ditandai pada Gambar 4 yaitu beberapa Kansei Words berikut "Informatif", "Elegan", "Bersemangat", "serasi", "Indah", "Inofatif/ "Kreatif", "Modern", "Fun”, "Colorfull”, "Dinamis" dan 'Unik' termasuk dalam Kansei Words yang berada dalam wilayah konsep Kansei Words yang ditandai.

\section{PC Score}

Digunakan untuk mengetahui hubungan antara emotion dan spesimen pada E-learning.

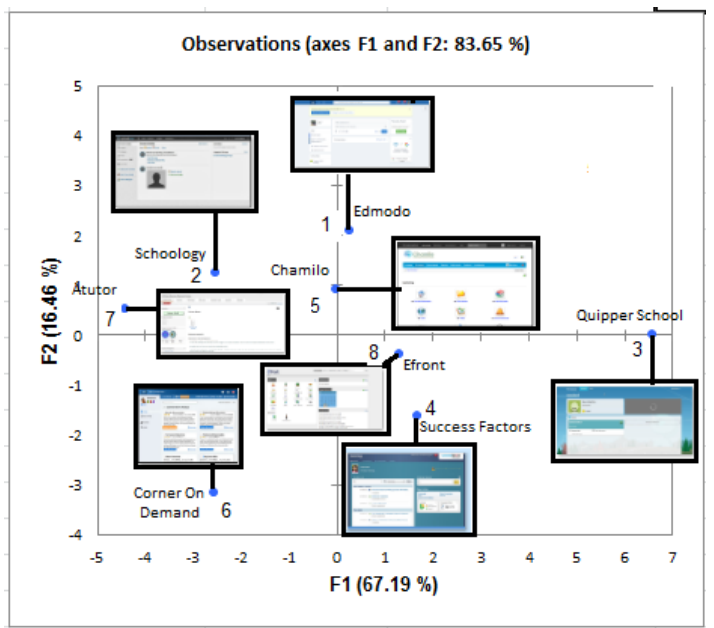

Gambar 5. PC Score F1 dan F2 untuk Seluruh Responden

Pada Gambar 5 terlihat hasil PC Score serta sebaran screenshot spesimen, dapat diketahui dari sebaran screenshot tersebut bahwa spesimen satu, tiga, empat dan delapan dapat dikategorikan sebagai 
spesimen yang dominan paling disukai oleh responden karena berada dalam wilayah axis x positif sedangkan sisanya yang berada dalam wilayah axis $\mathrm{x}$ negatif dengan asumsi spesimen tersebut tidak disukai oleh responden.

\section{PC Vector}

Digunakan untuk mengetahui seberapa besar pengaruh emotion terhadap spesimen E-learning, menentukan juga area Kansei dalam penentuan usulan desain perancangan desain E-learning berbasis web.

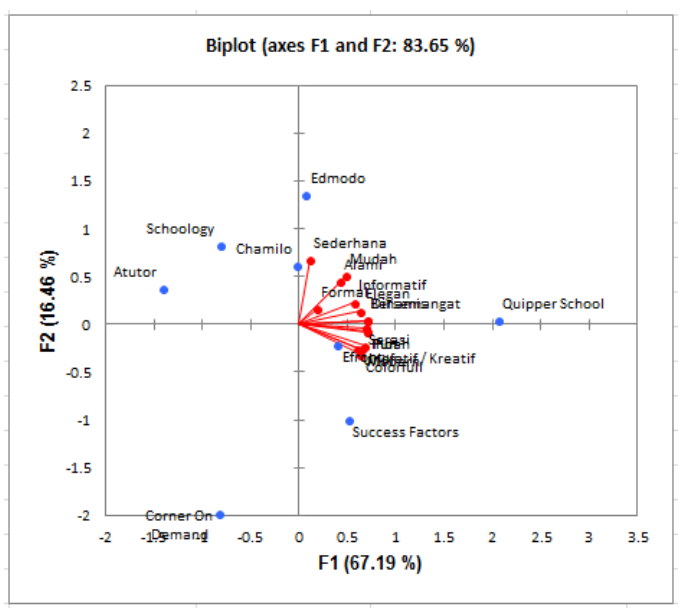

Gambar 6. PC Vector F1 dan F2 untuk Seluruh Responden

\subsection{Factor Analysis}

Metode Factor Analysis (FA) digunakan dalam mengamati konsep Kansei Words, FA dilakukan untuk menemukan faktor yang signifikan dari Kansei Words untuk menentukan konsep inovasi baru dalam desain aplikasi E-learning. Dengan hasil yang akan digunakan untuk menyempurnakan hasil analisis yang telah dilakukan sebelumnya dalam Principal component Analysis.

1. Factor Analysis untuk Seluruh Responden

Pada Tabel 9 menunjukkan hasil FA setelah varimax rotation dengan sumber data yang digunakan yaitu rata-rata data hasil kuesioner seluruh responden yang telah ditunjukkan pada Tabel 6.

Tabel 6. Hasil analisis faktor seluruh responden setelah Varimax Rotation

\begin{tabular}{lll}
\hline & Faktor 1 & Faktor 2 \\
\hline Variability (\%) & 66.731 & 16.068 \\
Cumulative (\%) & 66.731 & 82.799 \\
\hline
\end{tabular}

Pada tabel 6 terdapat dua faktor dengan masingmasing variability sebesar $66.731 \%$ untuk faktor 1 dan $16.068 \%$ untuk faktor 2. Jika melihat hasil pengolahan data dari PCA dan ketika dibandingkan dengan FA maka dapat diketahui tingkat keberpengaruhan faktor 1 dan faktor 2 dari hasil FA sejalan dengan F1 dan F2 dari PCA setelah varimax rotation.

Pada Tabel 7 merupakan hasil perhitungan FA yang berasal dari rata-rata hasil kuisioner.
Tabel 7. Korelasi Faktor dan Kansei Words Setelah Varimax Rotation

\begin{tabular}{|c|c|c|}
\hline Variabel & $\mathrm{F} 1$ & $\mathrm{~F} 2$ \\
\hline Dinamis & 0.984 & 0.063 \\
\hline Modern & 0.904 & -0.353 \\
\hline inofatif / Kreatif & 0.931 & -0.298 \\
\hline Sederhana & 0.161 & 0.948 \\
\hline Alami & 0.581 & 0.613 \\
\hline Serasi & 0.940 & -0.062 \\
\hline Unik & 0.835 & -0.324 \\
\hline Colorfull & 0.880 & -0.432 \\
\hline$\ldots$ & $\ldots$ & $\ldots$ \\
\hline
\end{tabular}

Selanjutnya data dari Tabel 7 disusun terurut dari nilai yang terkecil hingga terbesar untuk mengetahui Kansei Words yang memiliki pengaruh terbesar. Setelah melalui proses sorting data akan yang terlihat seperti pada Tabel 8 dengan nilai minimum yang digunakan adalah > 0.7 namun untuk mempersempit jumlah dan berfokus terhadap Kansei Words yang memiliki nilai pengaruh besar maka diambil nilai > 0.8 dengan Kansei Words pada Faktor 1 adalah "unik", "Colorfull", "Elegan", "Modern", "Inofatif/ kreatif", "Serasi", "Indah", "Bersemangat", "Fun" dan "Dinamis" yang kemudian secara subjektif Kansei Words tersebut terangkum menjadi konsep "Kenyamanan" atau "Coziness". Pada faktor kedua terdapat satu Kansei Word yang mempunyai nilai mendekati 1 atau > 0.8 yaitu "Sederhana", yang kemudian secara subjektif diberi nama "Sederhana" atau "Simple".

Tabel 8. Factor Loading seluruh responden untuk kansei word setelah sorting

\begin{tabular}{lclc}
\hline \multicolumn{1}{c}{ Kansei Word } & Faktor 1 & Kansei Word & Faktor 2 \\
\hline Sederhana & 0.162 & Colorfull & -0.432 \\
Formal & 0.265 & Modern & -0.353 \\
\multicolumn{1}{c}{$\ldots$} & $\ldots$ & $\ldots$ & $\ldots$ \\
Informatif & 0.783 & Indah & -0.114 \\
Unik & 0.831 & Fun & -0.093 \\
Colorfull & 0.877 & Serasi & -0.062 \\
Elegan & 0.881 & Bersemangat & 0.048 \\
Modern & 0.899 & Dinamis & 0.063 \\
inofatif/ Kreatif & 0.925 & Formal & 0.167 \\
Serasi & 0.944 & Elegan & 0.178 \\
Indah & 0.969 & Informatif & 0.295 \\
Bersemangat & 0.971 & Alami & 0.613 \\
Fun & 0.977 & Mudah & 0.703 \\
Dinamis & 0.981 & Sederhana & 0.948 \\
\hline (Coziness) & \multicolumn{3}{c}{ (Simple) } \\
\hline
\end{tabular}

\subsection{Menerjemahkan Data Statistik ke Elemen Desain Aplikasi E-learning}

Tahapan selanjutnya hasil dari analisis PCA dan FA akan diterjemahkan menjadi elemen desain dengan menggunakan analisis Partial Least Squere (PLS). Tujuan utama dari proses ini adalah untuk mengetahui elemen desain yang sangat mempengaruhi emosi partisipan. Hasil dari proses ini akan menjadi acuan untuk rekomendasi elemen desain sesuai dengan sasaran emosi partisipan. Data yang terlibat dalam proses analisis ini terdiri dari 3 elemen, diantaranya: 
1. Variabel y (Dependent), yaitu hasil rekapitulasi rata-rata partisipan.

2. Variabel $x$ (Independent), yaitu elemen desain yang diterjemahkan ke dalam Dummy variabel dengan mengubah tanda ceklis diberi nilai 1 dan kolom kosong diberi nilai 0 .

3. 8 spesimen aplikasi E-learning.

Data dari hasil klasifikasi elemen desain kemudian diubah nilainya seperti yang akan ditunjukan pada Tabel 8 Dummy variable. Nilai dari setiap elemen desain hanya memeiliki nilai 1 dan 0 . Artinya jika nilai dari sub elemen desain sama dengan 1 maka sub elemen tersebut yang terpilih, sebailiknya jika nilai sub elemen desain sama dengan 0 maka sub elemen desain tersebut tidak terpilih.

Tabel 8. Dummy Variable Elemen Desain

\begin{tabular}{lllllll}
\hline Variabel & BCW & BCG & BCB & BF1 & BF2 & BF3 \\
\hline Edmodo & 0 & 1 & 0 & 0 & 1 & 1 \\
Schoology & 0 & 1 & 0 & 1 & 0 & 1 \\
quipper school & 0 & 0 & 1 & 1 & 0 & 0 \\
succes factors & 0 & 0 & 1 & 0 & 1 & 1 \\
Chamilo & 1 & 0 & 0 & 1 & 0 & 1 \\
corner on demand & 0 & 1 & 0 & 1 & 0 & 0 \\
Atutor & 1 & 0 & 0 & 0 & 1 & 1 \\
Efront & 0 & 1 & 0 & 0 & 1 & 0
\end{tabular}

Keterangan :

BCW : Background Color White; BF1 : Body Font Size 10px BCG : Background Color Gray; BF2 : Body Font Size 12px BCB : Background Color Blue; BF3 : Body Font type arial

Data Dummy Variabel tersebut kemudian diolah dengan PLS Regression software XLSTAT 2017 dengan melibatkan data rata-rata hasil kuesioner dan data elemen desain 8 spesimen. Hasil tersebut menunjukan nilai Coefficient dari setiap variabel emosi yang terpilih dari konsep emosi. Tabel 9 menunjukan hasil dari analisis PLS. Data yang ditampilkan hanya konsep emosi yang memiliki nilai variabel tertinggi berdasarkan hasil dari analisis PCA dan FA.

Tabel 9. Hasil Perhitungan PLS Menerjemahkan Konsep Emosi Terpilih untuk Seluruh Responden

\begin{tabular}{ll}
\hline Variabel & Coefficient Dinamis \\
\hline Background Color White & -0.061 \\
Background Color Gray & -0.033 \\
Background Color Blue & 0.105 \\
Body Font Size 10px & 0.013 \\
Body Font Size 12 px & -0.013 \\
Body Font type Arial & -0.058 \\
Body Font typr Calibri & 0.028 \\
Body Font type Helvetica & 0.056 \\
Header Color White & 0.000 \\
Header Color Gray & -0.041 \\
... & $\ldots$ \\
\hline
\end{tabular}

Kemudian untuk mengetahui seberapa besar nilai pengaruh variabel (elemen desain) terhadap konsep emosi partisipan maka dicari nilai range elemennya dengan mengikuti langkah-langkah seperti pada Gambar 7.

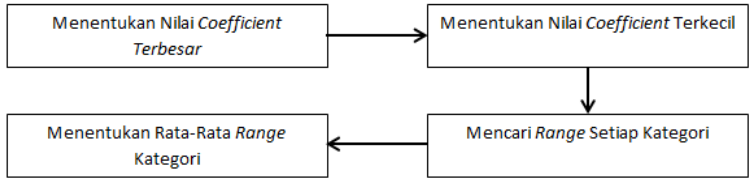

Gambar 7. Langkah-langkah Mencari Nilai Range Elemen

1. Menentukan nilai Coefficient terbesar variabel dalam satu kategori

2. Menentukan nilai Coefficient terkecil variabel dalam satu kategori

3. Mencari selisih nilai Coefficient terbesar dan terkecil dengan rumus Coefficient (Max) Coefficient (Min), Lakukan cara yang sama untuk seluruh kategori di bawahnya

4. Setelah seluruh nilai range kategori ditentukan, cari nilai range patokan dengan menghitung ratarata hasil range Kategori.

Nilai range kategori tertinggi memiliki pengaruh kuat terhadap konsep emotion, sedangkan range kategori yang memiliki nilai dibawah range patokan tidak memiliki pengaruh terhadap konsep emotion. seperti ditunjukan pada Tabel 10, dari 13 variabel pada Background Color, Background Color Blue yang memiliki nilai Coefficient tertinggi yakni 0.105 (cell yang diberi warna orange) dan Background Color White yang memiliki nilai Coefficient terendah yakni -0.061 (cell yang diberi warna biru muda), maka berdasarkan rumus tersebut $0.105-(-0.061)$ sehingga menghasilkan nilai range sebesar 0.166 (cell yang diberi warna hijau).

Tabel 10. Hasil perhitungan kategori range berdasarkan Kansei Words "dinamis" dari data seluruh responden

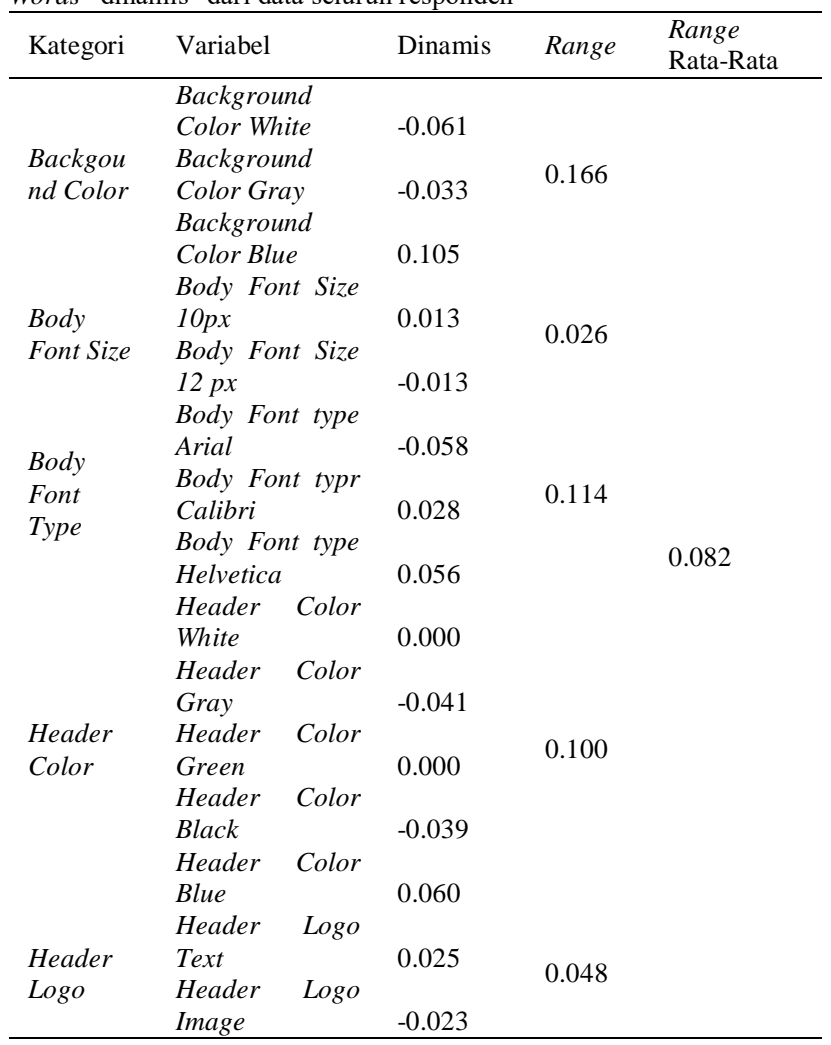




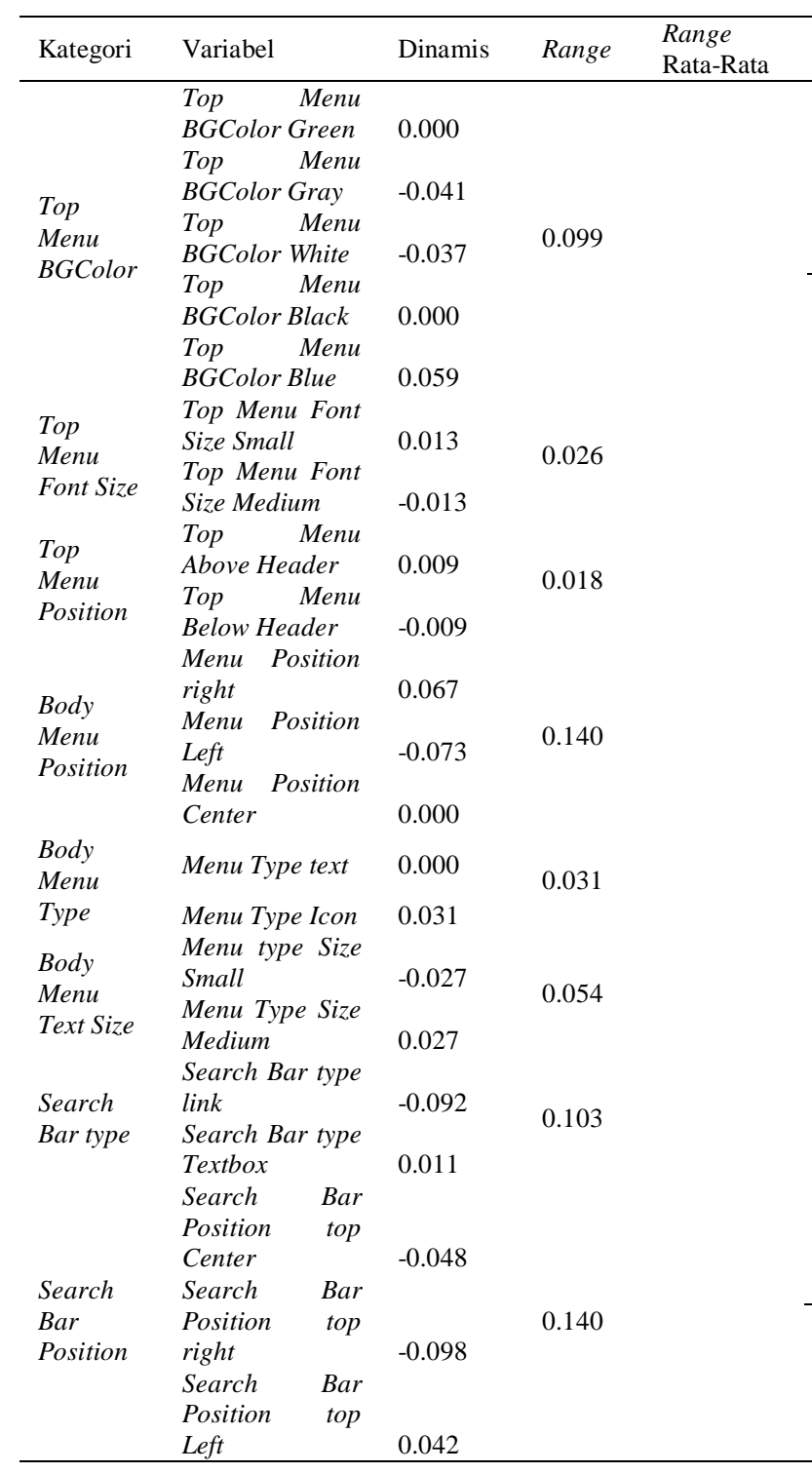

berdasarkan nilai range paling besar hingga paling kecil dengan tujuan dapat diketahui nilai range yang lebih besar dari nilai rata-rata range seperti yang terlihat pada Tabel 11 .

Tabel 11. Rekomendasi elemen desain hasil analisis Kansei Engineering seluruh responden

\begin{tabular}{|c|c|c|c|}
\hline \multirow{3}{*}{ Kategori } & \multirow{2}{*}{\multicolumn{2}{|c|}{ Konsep Emosi : Dinamis }} & \multirow{2}{*}{$\frac{\text { Range Dinamis }}{\text { Range Rata-Rata }}$} \\
\hline & & & \\
\hline & Konsep Desain & Coefficient & $\begin{array}{l}0.082 \\
\text { Range }\end{array}$ \\
\hline $\begin{array}{l}\text { Backgound } \\
\text { Color }\end{array}$ & $\begin{array}{l}\text { Background } \\
\text { Color Blue }\end{array}$ & 0.105 & 0.166 \\
\hline $\begin{array}{l}\text { Body Мепи } \\
\text { Position }\end{array}$ & $\begin{array}{l}\text { Menu Position } \\
\text { Right }\end{array}$ & 0.067 & 0.14 \\
\hline $\begin{array}{l}\text { Search Bar } \\
\text { Position }\end{array}$ & $\begin{array}{l}\text { Search bar } \\
\text { Position Left }\end{array}$ & 0.042 & 0.14 \\
\hline Body Font Type & $\begin{array}{l}\text { Body Font Type } \\
\text { Helvetica }\end{array}$ & 0.056 & 0.114 \\
\hline $\begin{array}{l}\text { Search Bar } \\
\text { type }\end{array}$ & $\begin{array}{l}\text { Search Bar } \\
\text { Textbox }\end{array}$ & 0.011 & 0.103 \\
\hline Header Color & $\begin{array}{l}\text { Header Color } \\
\text { Blue }\end{array}$ & 0.060 & 0.1 \\
\hline $\begin{array}{l}\text { Top Menu } \\
\text { BGColor }\end{array}$ & $\begin{array}{l}\text { Tор Мепи BG } \\
\text { Color Blue }\end{array}$ & 0.059 & 0.099 \\
\hline $\begin{array}{l}\text { Body Mепи } \\
\text { Text Size }\end{array}$ & $\begin{array}{l}\text { Menu Text Size } \\
\text { Medium }\end{array}$ & 0.027 & 0.054 \\
\hline Header Logo & $\begin{array}{l}\text { Header Logo } \\
\text { Text }\end{array}$ & 0.025 & 0.048 \\
\hline $\begin{array}{l}\text { Body Мепи } \\
\text { Type }\end{array}$ & $\begin{array}{l}\text { Mепи Tуре } \\
\text { Icon }\end{array}$ & 0.031 & 0.031 \\
\hline Body Font Size & $\begin{array}{l}\text { Body Font Size } \\
10 p x\end{array}$ & 0.013 & 0.026 \\
\hline $\begin{array}{l}\text { Top Mепи Font } \\
\text { Size }\end{array}$ & $\begin{array}{l}\text { Top Menu Font } \\
\text { Size Small }\end{array}$ & 0.013 & 0.026 \\
\hline $\begin{array}{l}\text { Tор Мепи } \\
\text { Position }\end{array}$ & $\begin{array}{l}\text { Top Menu } \\
\text { Above Header }\end{array}$ & 0.009 & 0.018 \\
\hline
\end{tabular}

\subsection{Membuat Usulan Desain Hasil Kansei} Engineering

Tahap akhir dari penelitian ini adalah membuat usulan desain berdasarkan rekomendasi matrik hasil

Setelah semua emosi berhasil ditentukan nilai range kategori beserta nilai range patokannya. Nilainilai kategori yang lebih besar atau sama dengan nilai range patokan, memiliki pengaruh kuat dalam konsep desain tampilan aplikasi E-learning

\subsection{Matriks Hasil Analisis Kansei Engineering}

Tahap selanjutnya adalah membuat rekomendasi konsep desain tampilan aplikasi E-learning. Berdasarkan hasil perhitungan PLS dapat dibuat matrik rekomendasi konsep desain tampilan. Elemen desain yang memiliki nilai range di atas nilai ratarata seluruh range adalah Elemen desain yang direkomendasikan. Elemen-elemen desain tersebut berdasarkan hasil analisis dapat memberikan pengaruh emosi terhadap pengguna aplikasi. Kansei Words tersebut akan menjadi referensi dalam perancangan usulan matriks, selanjutnya proses penyusunan matriks usulan aplikasi E-learing akan dilakukan dengan cara manual menggunakan hasil analisis PLS dimana data kategori yang sudah diurut analisis Kansei Engineering yang direkomendasikan untuk desain tampilan aplikasi E-learning. Gambar 8 untuk tampilan bagi pengguna umum aplikasi $E$ learning, yang bersumber dari proses Kansei Engineering seluruh partisipan.

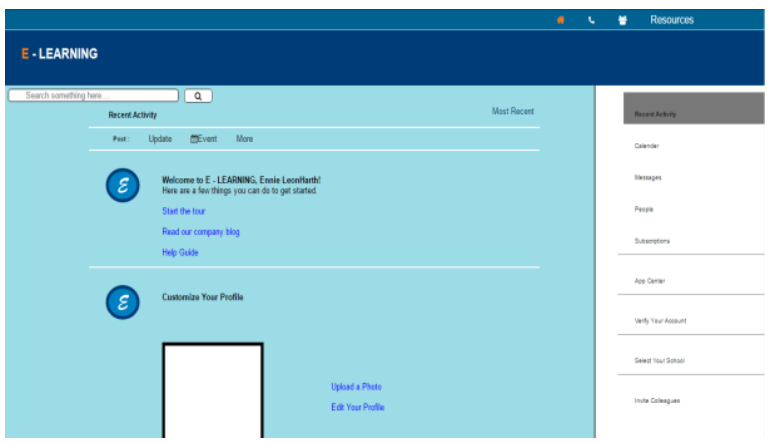

Gambar 8. Rekomendasi tampilan Html dan CSS dari seluruh partisipan 


\section{Kesimpulan}

Pada penelitian ini dapat disimpulkan antara lain sebagai berikut :

1. Dalam penelitian ini elemen-elemen desain tampilan untuk merancang aplikasi $E$ learning dibagi menjadi 3 bagian besar yaitu bagian Header, Main dan Footer. Dari 3 bagian tersebut dibagi menjadi 13 sub bagian, kemudian dari 13 sub bagian dibagi menjadi 36 elemen desain.

2. Dalam penelitian ini menggunkan 15 Kansei Word untuk mendeteksi perasaan pengguna aplikasi E-learning.

3. Proses menganalisis elemen-elemen yang diperlukan dalam merancang desain tampilan aplikasi E-learning dengan pendekatan Kansei Engineering, menggunakan metode perhitungan statistik multivariat. Metode tersebut adalah Cronbach's Alpha, Coefficient Correlation Analysis (CCA), Principal Component Analysis (PCA), Factor Analysis (FA) dan Partial Least Square (PLS)

4. Implementasi Kansei Engineering dalam membuat rekomendasi desain tampilan aplikasi E-learning menghasilkan 3 buah desain tampilan, yaitu :

a. Desain tampilan yang bersumber dari seluruh responden, yang akan digunakan untuk tampilan umum.

b. Desain tampilan yang bersumber dari responden siswa-siswi SMK PGRI 3 Cimahi, yang akan digunakan oleh siswa-siswi SMK PGRI 3 Cimahi

c. Desain tampilan yang bersumber dari responden siswa-siswi SMK Negeri 4 Padalarang, yang akan digunakan oleh siswasiswi SMK Negeri 4 Padalarang

5. Menurut hasil dari proses perhitungan FA setiap kelompok responden menghasilkan tiga konsep Kansei Word.

a. Konsep desain bersumber dari seluruh responden memiliki konsep emosi yang paling kuat pengaruhnya adalah "Dinamis", oleh karena itu dibuat Tabel rekomendasi elemen desain berdasarkan konsep emosi tersebut (dapat dilihat pada Tabel 11).

b. Konsep desain bersumber dari responden SMK PGRI 3 Cimahi memiliki konsep emosi yang paling kuat pengaruhnya adalah "Inofatif / Kreatif”, oleh karena itu dibuat Tabel rekomendasi elemen desain berdasarkan konsep emosi tersebut. c. Konsep desain bersumber dari responden SMK Negeri 4 Padalarang memiliki konsep emosi yang paling kuat pengaruhnya adalah "Fun". Oleh karena itu dibuat Tabel rekomendasi elemen desain berdasarkan konsep emosi.

6. Dari ketiga konsep desain yang dihasilkan, masing-masing dibuat prototype tampilan menggunakan dokumen HTML dan CSS.

\section{Daftar Pustaka}

Hartley, D.E., 2001. Selling E-Learning. United State Of America: American Society for Training and Development.

Kurosau, M., 2016. Human Computer Interaction. Toronto: Springers.

Lokman, A.M., 2009a. Emotional User Experience in Web Design : The Kansei Engineering. Universitas Teknologi Maya (UTIM) Malaysia.

Lokman, A.M., 2009b. Kansei Database System for Emotion Interface Design of E-commerce Website. ResearchGate.

Lokman, A.M., 2009c. Kansei Structure and Visualization of Clothing Websites Cluster. ResearchGate.

Lokman, A.M., 2010. Design \& Emotion : The Kansei Engineering Methodology. ISSN 22317473, 4-8.

Lokman, A.M., Haron, M.B.C., Abidin, S.Z.Z., Khalid, N.E.A., Ishihara, S., 2013. Prelude to natphoric kansei engineering framework. Journal of Software Engineering and Applications, Vol 6, 638-644.

Mindra, J. dan Sumertajaya, I.M., 2008. Pemodelan persamaan struktural dengan partial Least Square. Prosiding Seminar Nasional Matematika dan Pendidikan Matematika. ISSN 978-979-16353-18

Nagamachi, M. 2011. Innovations of Kansei Engineering. Japan: CRC Press.

Rusmana. 2011. Model-Model Pembelajaran. Jakarta: Raja Grafindo Persada.

Wiley, J. 2015. Interaction Design. United Kingdom: The Atrium.

Yaniawati, R. P. 2010. E-Learning Alternatif Pembelajaran Kontemporer. Bandung: Arlino Raya. 